\title{
ВКЛАД К.И. САТПАЕВА В СТАНОВЛЕНИЕ АРХЕОЛОГИЧЕСКОЙ НАУКИ КАЗАХСТАНА
}

\author{
(C) 2019 г. М.В. Бедельбаева
}

В статье, посвященной 120-летию со дня рождения академика К.И. Сатпаева, рассмотрен вклад выдающегося ученого и талантливого организатора науки в развитие археологии Казахстана. Еще в юности он активно интересовался древней и средневековой историей, увлеченно собирал и записывал образцы устного народного творчества казахов, отражающего период Золотой Орды. В студенческие годы, во время учебы в Томском технологическом университете, начинающий исследователь продолжил сбор материалов о Едиге-батыре в академических библиотеках и архивах. В ходе геологических изысканий в Центральном Казахстане (Улытауский район Карагандинской области) К.И. Сатпаев с интересом описывал материальные свидетельства ушедших эпох - отдельные артефакты, наскальные рисунки, древние рудные разработки, курганы, менгиры, балбалы, мавзолеи, не ограничиваясь лишь фиксацией их расположения, а осуществляя попытки периодизации и воспроизведения исторического контекста. Содержательные выводы геолога-профессионала включали детальную реконструкцию процессов добычи, первичного обогащения и выплавки цветных металлов, а математические подсчеты, основанные на многолетнем полевом опыте, позволили предположить количество добытой в древности медной руды, составляющей не менее 1000000 т. Широта исторических взглядов и талант полевого исследователя позволили К.И. Сатпаеву не только обнаружить плиту с надписью Тамерлана на сопке Алтыншокы, известную в науке как «карсакпайская», но и сделать ее прочтение достоянием мировой науки, привлекающей исследователей новыми аспектами вплоть до настоящего времени. К.И. Сатпаев лично не участвовал в археологических раскопках. Но плодотворная научная деятельность и организаторский талант первого президента Академии наук Казахской ССР способствовали открытию сектора археологии в Институте истории, археологии и этнографии, созданию Центрально-Казахстанской археологической экспедиции, формированию национальной школы археологии и профессиональному становлению целой плеяды известных археологов.

Ключевые слова: археология, К.И. Сатпаев, Центральный Казахстан, древние памятники, музеи, рудники, экспедиция

Научное наследие Каныша Имантаевича Сатпаева включает более 800 статей, среди которых следует особо отметить ряд публикаций, непосредственно посвященных древней истории Казахстана. Своей активной деятельностью по поис- ку и фиксации памятников материальной культуры, изучению древнего горного дела и медеплавильного производства, сохранению образцов устного народного творчества казахов К.И. Сатпаев заслужил непререкаемый авторитет в исторической 
науке. Еще при жизни академика известный советский ученый-археолог С.С. Черников в статье «Основные проблемы археологического изучения Казахстана», опубликованной в 1950 году в журнале «Известия АН КазССР», обозначил ключевую роль К.И. Сатпаева как учёного, стоящего у истоков археологической науки Казахстана: «Первым археологомказахом по праву должен считаться К.И. Сатпаев, собравший ценные сведения по древним выработкам Джезказгана и составивший сводку археологических памятников этого района» [цит. по: Бейсенов и др., 2017, с. 17]. В фундаментальном издании «Древняя культура Центрального Казахстана», удостоенном премии им. Ч. Валиханова и вышедшем в свет в 1966 году вскоре после смерти К.И. Сатпаева, авторы - известные казахстанские археологи - поместили эпиграф: «Светлой памяти первого президента Академии наук Казахской ССР, исследователя Центрального Казахстана, академика Каныша Имантаевича Сатпаева посвящается этот труд» [Маргулан и др., 1966, c. 3]. Это знак глубокой признательности К.И. Сатпаеву за личный вклад в становление и развитие казахстанской археологии.

Академик К.И. Сатпаев, 120летие со дня рождения которого отмечается в этом году, был многогранной, уникальной личностью, настоящим патриотом родного края. Поэтому совершенно закономерным проявлением его личностных качеств явился неугасающий интерес к истории и этнографии, который он пронёс через всю жизнь.

Первоначально это было юношеское увлечение топонимикой, географией, орографией, геологией, ги- дрологией, устным народным творчеством казахов, в частности, эпосом о Едыге-батыре. В период работы народным судьей в Баянаульском районе исследователь записывал различные образцы сказания, беседуя с местными жителями. В научно-популярной литературе о К.И. Сатпаеве упоминаются его информаторы и проводники, к которым он относился с большой теплотой и уважением: К. Жидебаев, Ж. Кенесулы, Р. Жаппасбаев, Омеке, Б. Султангазиев и другие старейшины казахских родов Баянаула и Улытау. К.И. Сатпаев доверительно беседовал со старожилами, и записывал с их слов легенды, предания, объясняющие происхождение различных топонимов. Учёный видел в таких беседах неисчерпаемый источник познания и полагал, что предания хранят память о важных исторических событиях и могут стать основанием для замечательных открытий.

Обратимся к воспоминаниям М.П. Русакова*, [*известный геолог-исследователь Центрального Казахстана, первооткрыватель Коунрадского месторождения меди, академик АН КазССР - прим. авт.], многолетняя дружба с которым во многом способствовала становлению профессионализма К.И. Сатпаева. Вот что писал он о студенческой практике К. Сатпаева в его геологической партии в урочище Бес-Шоку: «<..> не одна геология интересовала его. После утомительного маршрута, после жаркого дня во время кочевки в ауле, среди живописной природы и трудовой жизни скотоводов, Каныш Имантаевич находил в себе силы подолгу вести разговоры с аксакалами при свете костра в юрте, слушать их рассказы о старине, о разных находках в степи $<\ldots>$ Уже тогда зародился 
в нем интерес к археологии и фольклору родного казахского народа» [цит. по: Батырбеков, 1999, с. 126].

Пытливый ум юноши и жажда познания в полной мере проявились во время учёбы в Томском технологическом университете. К.И. Сатпаев не только овладевал самым современным уровнем знаний по будущей профессии, что позволяла сделать хорошая научная школа и традиции университета, но и стремился к углубленному изучению истории и культуры казахов. По его инициативе в годы студенчества был организован научный кружок по изучению культуры восточных народов. Есть сведения И.Т. Лозовского о том, что студент «<..> Каныш Сатпаев создал и возглавил казахскую секцию археологического музея при Томском университете» [Лозовский, Сипайлов, 1999, с. 24].

\section{Академик А.Х. Маргулан,} близкий друг К.И. Сатпаева, с которым они вместе учились в Семипалатинской учительской семинарии, рассказывал, что Каныш всегда много и увлеченно читал. Прекрасные возможности для исследовательской деятельности К. Сатпаев открыл для себя в библиотеке Томского университета, где была собрана богатая коллекция книг, текстов и документов по истории казахов. Проводя все свободное время в библиотеке, он изучал источники по истории периода Золотой Орды, читал труды Ч. Валиханова, П.С. Палласа, В.В. Радлова, П.М. Мелиоранского, И.И. Веселовского, Г.Н. Потанина и др. К.И. Сатпаев искал соответствия и параллели сюжетов эпоса «Ер Едыге» с политическими событиями междоусобной борьбы и противостояния хана Токтамыша и Едыге, и пришел к выводам, совпа- дающим с мнением Ч. Валиханова: «Существование Идыге, несомненно, как существование Тохтамыш-хана и Тамерлана $<\ldots>$ Западная часть горы Улытау в Средней орде, составляющая совершенно отдельный утес от главного хребта, называется Идыге. На вершине этого утеса есть курган, сложенный из плитняка и бута; курган этот, имеющий форму всех оба (по-монгольски - обо), т.е. курганов, воздвигнутых в честь и воспоминание падших или умерших героев, называется Идыген обасы; самая гора называется просто Идыге. Киргизы* [*казахи - прим. авт.], почитая его, как национального героя и святого по происхождению, часто приносят на могиле его жертвы. Иногда режут скот, что теперь очень редко, а большею частью привязывают к растущему тут кустарнику лоскутки одежды и конские волосы» [Потанин, 1985, c. 297].

Известно, что первый вариант эпоса «Ер Едыге» записал на русском языке Ч. Валиханов, второй - российский филолог П.М. Мелиоранский на казахском языке. К.И. Сатпаев изучил эти тексты, представленные в библиотеке Томского университета, верифицировал их и подготовил новую редакцию текста эпоса.

Эпос «Ер Едыге» был издан в 1927 году в Москве в издательстве «Восточных народов СССР» с авторским предисловием Каныша Имантаевича, которое является результатом серьезной аналитической работы автора и существенным вкладом в изучение средневековой истории Казахстана. При организационной помощи А. Букейханова удалось выпустить книгу достаточно солидным тиражом - три тысячи экземпляров. Текст эпоса был представлен на ка- 
захском языке арабской графикой (рис. 1). Позднее, в 1951 году, именно эта книга стала основанием для ярлыка «казахский националист», что, наряду с другими обвинениями, едва не погубило карьеру К.И. Сатпаева.

В 1929 г. К.И. Сатпаев впервые приехал в пос. Карсакпай (Улытауский район Карагандинской области) с назначением на должность главного геолога геолого-разведочного комбината Главцветмета Наркомата тяжелой промышленности СССР. Молодому специалисту были отпущены ничтожно малые средства на проведение геолого-разведочных работ в данном регионе, но в этом был

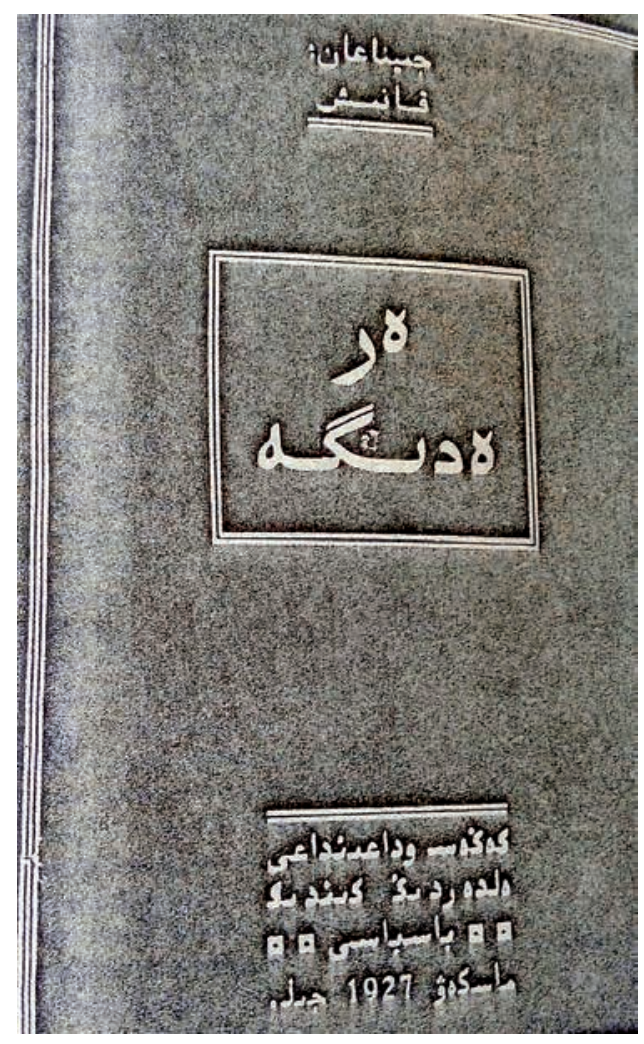

Рис. 1. Обложка первого издания книги «Ер Едыге», изданной под редакиией К.И. Сатпаева (no: [Сатпаева, 1999, с. 58])

Fig. 1. Cover of the first edition of the book "Er Edige», edited by K.I. Satpayev (by: [Satpayeva, 1999, p. 58]) свой положительный эффект: огромные территории исследовались посредством пеших разведок, что дало возможность не только обнаружить местонахождения полезных ископаемых, но и выявить и зафиксировать местонахождение многих памятников древней истории (древние рудные разработки, курганы, наскальные рисунки и др.).

Именно в эти годы в беседе с одним из местных жителей он услышал рассказ о камне необычной формы «с меткой на одной стороне». В качестве ориентира была указана каменная насыпь на вершине сопки площадью приблизительно с окружность юрты [Сарсеке, 2018, с. 507]. Тогда К.И. Сатпаев ещё не предполагал, что этот рассказ позволит сделать ему научное открытие мирового уровня. Но прекрасная интуиция, настойчивость и стремление к неизведанному через года вели учёного к важной находке. В 1935 году в ходе геологической разведки К.И. Сатпаевым была обнаружена «<..> широкая каменная плита, на которой арабским шрифтом красиво высечены письмена» [Сатпаев, 2007, с. 48], сразу заинтересовавшая молодого геолога. Благодаря фотографиям, сделанным коллектором С.А. Рожновым, работавшим в геологических разведках вместе с К.И. Сатпаевым, мы можем увидеть момент находки плиты с надписью Тимура о походе против хана Токтамыша на склоне сопки Алтыншокы в горах Улытау, что явилось настоящим открытием для мировой науки (рис. 2, 3).

С детства знакомый с арабским алфавитом К.И. Сатпаев (в начальной аульной школе, где он учился, преподавание велось на арабском языке), хоть и с трудом, но прочел едва видимые, нечетко процарапанные три первые строки надписи, содержащие традиционное для мусульман восхваление Аллаху, предшествующее 
Бедельбаева M.В. Вклад К.И. Сатпаева в становление археологической науки Казахстана

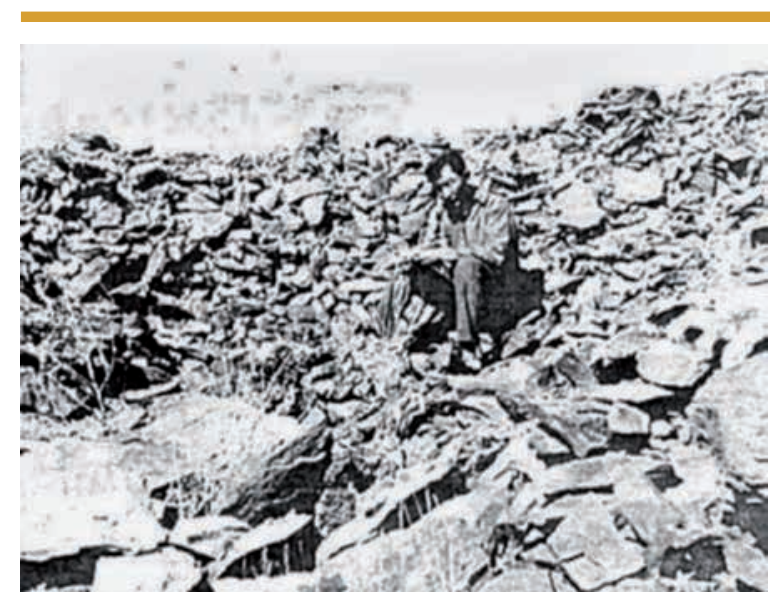

Рис. 2. К.И. Сатпаев на сопке Алтыншокы. Фото С.А. Рожнова, 1935 г. (по: [Индустриальная Караганда, 6 апреля 1999])

Fig. 2. K.I. Satpayev on the hill Altynshoky. Photo by S.A. Rozhnov, 1935 (by: [Industrial Karaganda, 6 April, 1999]) находит подтверждение при сравнении со строительным материалом и архитектурными особенностями осмотренных им мавзолеев Алашахана и Джучи/Жошы, расположенных в районе реки Кенгир, которые сложены из обожженного кирпича квадратной формы с глазурованными лицевыми поверхностями. Формы и размеры кирпича этих могильников наиболее близки «золотоордынскому» стилю.

В другой своей статье «Доисторические памятники в Джезказганском районе», опубликованной в 1941 г., К.И. Сатпаев пишет о «<..> началу всех писем и посланий. Другая часть надписи, выполненная на чагатайском языке, требовала расшифровки специалистов, что было сделано после передачи камня в государственный музей «Эрмитаж».

В последующем, в ряде статей К.И. Сатпаев высказал свои суждения о содержании и датировке надписи, а также о назначении сооружения из камней (насыпи) на вершине сопки. Исторические знания ученого и интуиция позволили ему предложить первую датировку этой надписи, которая была вполне профессиональной: «<..> письмо не древнее $\mathrm{XV}$ в. или даже позднее» [Сатпаев, 2007 , с. 48 ]. О самом сооружении на «вершине горы Алтын-Чеку, воздымающейся над богатыми пастбищами долины рек Сорели и Джетыкыз», К.И. Сатпаев пишет как об остатках «<..> «завода», где обжигались кирпичи с глазурованной поверхностью. На месте обжига сохранились куски кирпича и шлака» [Сатпаев, 2007, c. 48]. По его мнению, данная версия

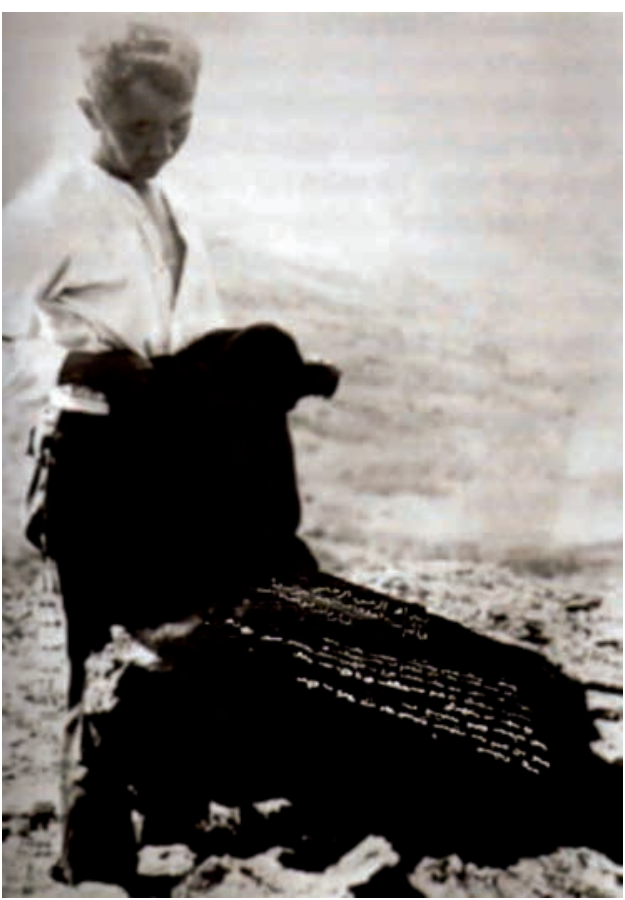

Рис. 3. К.И. Сатпаев у плиты с надписью на сопке Алтьнииокь. Фото С.А. Рожнова, 1935 2. (по: [Сарсеке, 2016, с. 508])

Fig. 3. K.I. Satpayev at the plate with the inscription on the hill Altynshoky.

Photo by S.A. Rozhnov, 1935 (by: [Sarseke, 2016, p. 508]) 
развалинах какого-то древнего сооружения, сложенного из кирпича и красивых амфиболитовых плит с ошлакованными и глазурованными поверхностями» и каменной плите с надписью из таких же темных амфиболитов. В тексте этой статьи К.И. Сатпаев приводит перевод надписи на чагатайском языке, выполненный профессором Н.Н. Поппе, и говорит об исторической достоверности эпизода, описанного средневековым ученым Язди [Сатпаев, 2007 , с. 74-75]. Этот факт из жизни К.И. Сатпаева четко показывает стремление подлинного ученого к научному осмыслению исторических памятников, пусть даже не связанных с профессиональной деятельностью геолога.

Подробно история прочтения надписи на камне Тимура изложена в ряде статей [Григорьев и др., 2003, c. 3-24; Крамаровский, 2005, с. 167170; Усманова и др., 2018, с. 7-24]. А.П. Григорьев, Н.Н. Телицина и О.Б. Фролова предлагают свою версию прочтения так называемой «карсакпайской надписи», а само сооружение на вершине сопки Алтыншокы, обнаруженное К.И. Сатпаевым, они ошибочно интерпретируют как «<..> громадную плавильную печь, сложенную из грубых камней и предназначенную, скорее всего, для вытапливания свинца из руды» [Григорьев и др., 2003, с. 20]. Вероятно, это заблуждение авторов было связано с особым вниманием, которое К.И. Сатпаев уделял в своих статьях плавильному делу древних племен Центрального Казахстана.

В настоящее время курган на вершине сопки Алтыншокы, как историческое сооружение, вновь привлек к себе внимание исследователей. Изучены особенности конструкции кур- ганной насыпи с восьмеркообразной выемкой в центре, содержащей большое количество шлака и прокаленного плитчатого базальта. Наличие семи отверстий от воздуходувных каналов в насыпи кургана дает возможность рассматривать его в качестве тепло-технического сооружения. В результате исследований, выполненных по проекту МОН РК «Изучение и документирование культурных ландшафтов Центрального Казахстана с применением современных технологий и междисциплинарных методов», инициированных научным сотрудником Сарыаркинского археологического института при КарГУ им. Е.А. Букетова Э.Р. Усмановой, проведен химический анализ шлаков из насыпи кургана, радиоуглеродное датирование, начато изучение природного ландшафта сопки Алтыншокы, в пространстве которого располагался военный лагерь войск Тимура. Публикация в 2018 г. статьи «Загадка сопки Алтыншокы: об одном эпизоде похода Тимура против Токтамыша в 1391 г.» [Усманова и др., 2018, c. 7-24] содержит следующий вывод авторов: курган на сопке Алтыншокы в виде сложного теплотехнического сооружения был сделан для гигантского обрядового костра, зажженного в честь поклонения предкам и Родовой Горе, и, вероятно, был призван обеспечить будущую победу Амира Тимура над ханом Токтамышем.

Таким образом, обнаружение К.И. Сатпаевым письменного свидетельства о походе Тимура предоставляет возможности для новых междисциплинарных исследований на современном уровне развития науки.

Помимо этой важной находки вклад К.И. Сатпаева в археологическое изучение Центрального Казахстана подтверждается открытием 
им множества памятников в окрестностях гор Улытау, Арганаты, верховьях реки Тургай. С.А. Рожнов вспоминал о большой тяге К.И. Сатпаева к детальному изучению археологических памятников. Он требовал их тщательной фотофиксации и с этой целью использовавшийся ранее С.А. Рожновым громоздкий деревянный английский фотоаппарат в 1935 г. был заменён на доставленный из Москвы по просьбе К.И. Сатпаева отечественный «Фотокор», что позволило улучшить качество снимков [Могильницкий, 1998, с. 29-30].

Каныш Имантаевич чётко обозначал историческую преемственность между горнорудной промышленностью Казахстана и традициями металлургии древности. Так, в 1936 г. в статье «Казахстанская медь», представляя подробные геологические характеристики крупнейших месторождений - Жезказган, Коунрад, Бозшаколь и др., - исследователь обязательно указывал для каждого «разрабатывалось в глубокой древности» [Сатпаев, 2007, с. 155-162]. «Первые горнопромышленные работы в районе Карагандинского бассейна велись, вероятно, еще в медную эпоху развития человечества. Следы этих работ, называемых в Степи чудскими, сохранились почти на всех более и менее значительных месторождениях Казахстана, причем зачастую эти старинные рудные отвалы и разработки служили главными основаниями производства заявок на медь в тех или иных местах Казахстана» [Сатпаев, 2007, с. 124]. К настоящему времени исследованиями ученых предметно доказано, что Центральный Казахстан является одной из ключевых точек добычи металла, зарождения и распространения плавильного производства и металлургических технологий.
В археологических раскопках К.И. Сатпаев сам никогда не участвовал, но с его помощью происходило накопление фонда археологических источников по Центральному Казахстану: на основании его данных в Археологическую карту Казахстана были включены десятки исторических объектов древности и средневековья [АКК, 1960, № 2041, 2048, 2050, 2052, 2060, 2082, 2120, 2815, 2830 и др.].

Это наскальные рисунки в долинах рек Байконыр, Талды-Эспе, Жетыкыз. Образцы творчества древних не оставили равнодушным исследователя - оставленное им довольно полное описание и предпринятая попытка их исторической интерпретации несомненно способствовали осмыслению значения изобразительных памятников. В настоящее время петроглифистика является отдельным научным направлением в археологии и К.И. Сатпаев был одним из «пионеров» отечественной петроглифистики.

К.И. Сатпаев внёс значимый вклад и в исследование статуарных памятников. Геолога удивляли установленные в Улытауской степи многочисленные каменные статуи, вырубленные из монолитных глыб. Им обследованы каменные изваяния на реке Жетыкыз и в районе гор Арганаты. По определению К.И. Сатпаева основным материалом для таких изваяний чаще всего служил розовый песчаник, выходы которого в горах Улытау неизвестны и, вероятнее всего, он привозился из других районов [Сатпаев, 2007, с. 45]. Благодаря врожденной и отшлифованной в профессиональной деятельности наблюдательности, К.И. Сатпаев обратил внимание на то, что в степях в районе гор Едиге и Арганаты чаще 
встречаются изваяния воинов, детализированные усами и предметами вооружения, а в долинах рек Жетыкыз и Бозай - изображения женские в характерных конических головных yборах.

А.Х. Маргулан, который вслед за К.И. Сатпаевым исследовал статуарные памятники и проанализировал 10 изваяний региона, писал, что высеченные из серого гранита балбалы более грубы в исполнении, чем те, которые сделаны из песчаника - он характеризует их как «<..> более гладкие, а иногда более искусные», делая вывод, что «<..> древние каменотесы хорошо знали из какого материала им легче и лучше сделать фигуру человека» [Маргулан, 1947, c. 57]. Детальное изучение каменных скульптур современными исследователями (Ж. Курманкулов, Л.Н. Ермоленко и др.) подтверждают предварительные выводы К.И. Сатпаева, детализируют иконографические особенности балбалов и даже психоэмоциональные характеристики выражения их лиц.

Представляет несомненный интерес описание традиционных родовых знаков-тамг, которые осмотрел К.И. Сатпаев в урочище Тамгалытас в Бетпакдале. Исследователь интерпретирует историческое значение этого памятника на основании записанной им народной легенды, содержащей этимологические сведения [Сатпаев, 2007, с. 47-48]. Тамги, имеющие важнейшую роль в жизни кочевников, в настоящее время вызывают интерес целого ряда исследователей (3. Самашев, А.И. Рогожинский, А.3. Бейсенов и др.). Так, А.И. Рогожинский, осмотревший это же урочище в 2009 г., задокументировал два местонахождения эпиграфики и удостоверительных знаков, где сохранилось более 60 изображений вместе с надписями на камне Тамгалытас. Он выделил два хронологических периода их нанесения (IXXI вв., соотносимый с племенами огузов, и XIX - начало XX в.) и провел типологическое сопоставление серии знаков с известными тамгами современных и средневековых кочевников региона [Рогожинский, 2017, c. 297-307]. Выявление и идентификация родоплеменных знаков среди наскальных изображений открывает дополнительные возможности для изучения истории расселения казахских племён в XVIII-XIX вв., для выяснения складывавшихся в степи на разных исторических этапах условий пользования земельными территориями.

Научную добросовестность К.И. Сатпаева как учёного, системный подход к исследованию исторических памятников, скрупулезность в обращении с собранными данными хорошо характеризует следующий факт. В ходе поездки с проводником из Карсакпайского района Р. Жаппасбаевым ученый не только подробно записал устные народные предания и легенды о мавзолее Сырлытам, уже полуразрушенном к тому времени, но и сделал эскиз внешней архитектуры здания, его внутреннего убранства, а также росписи стен могильника (рис. 4). Он пытался (к сожалению, безуспешно) разыскать в источниках сведения о личности погребенного. Позднее в своей статье К.И. Сатпаев приводит указание на фиксацию местонахождения данного мавзолея на берегу реки Джиланчик на военно-топографических картах 1894 г., разыскивает аналогии, делает выводы о времени строительства данного сооружения - домусульманский период, до XI в. н.э. [Сатпаев, 2007, с. 73-74]. 
Бедельбаева М.B. Вклад К.И. Сатпаева в становление археологической науки Казахстана

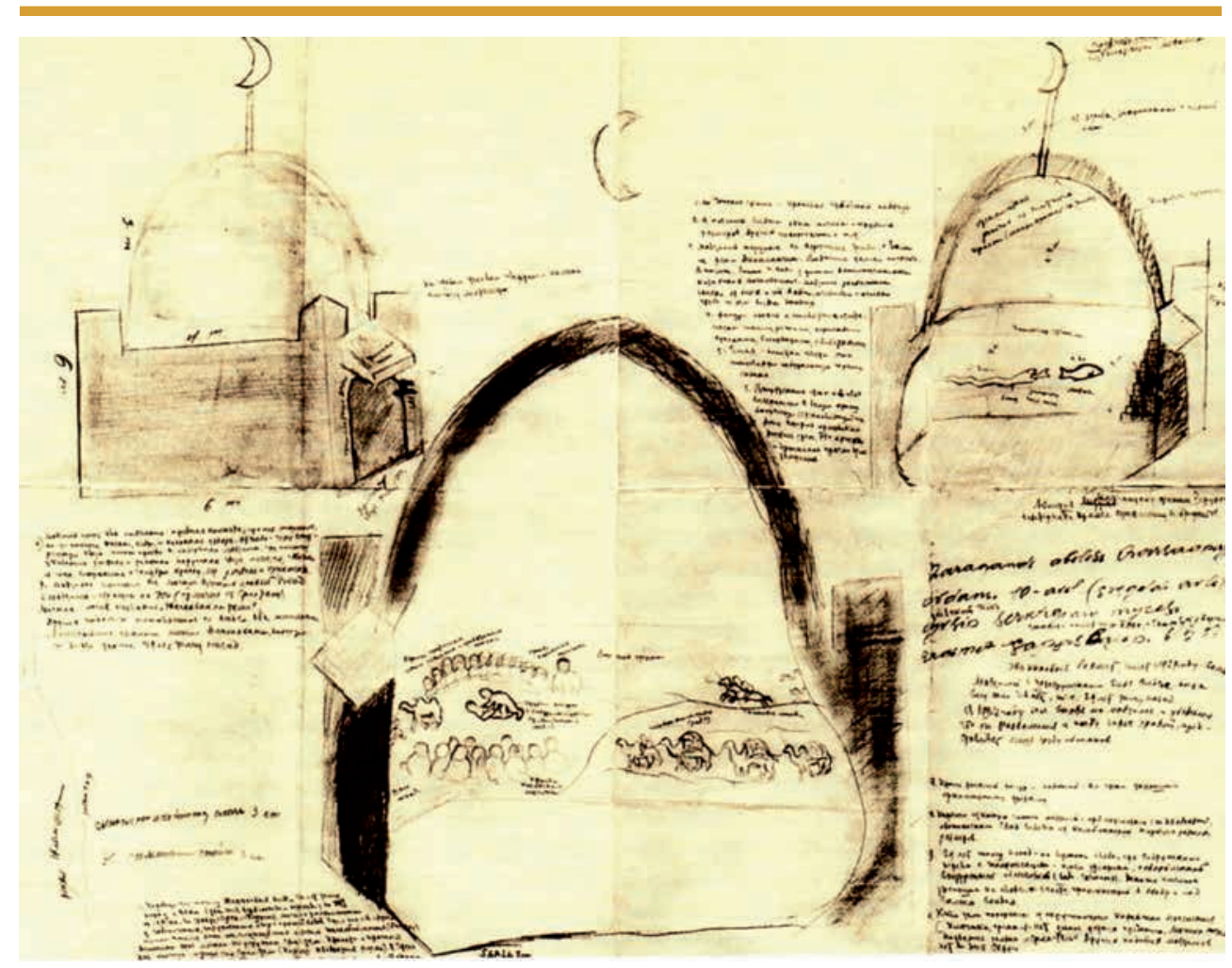

Рис. 4. Эскиз архитектуры, надгробия и внутренних росписей мавзолея Сырлытам, Улытауский район. Изображение с пояснительными надписями из полевой тетради К.И. Сатпаева (по: [Сарсеке, 2015, с. 508])

Fig. 4. Sketch of architecture, tombstones and interior paintings of the mausoleum Syrlytam, Ulytau district. Image with explanatory inscriptions from K.I. Satpayev's field notebook (by: [Sarseke, 2015, p. 508])

Огромные валыгородищ, остатки древних оросительных систем, курганы и могильники, архитектурные памятники и мавзолеи, рудные выработки, случайные находки - все эти многочисленные памятники старины укрепили К.И. Сатпаева в мысли, что район гор Улытау в прошлом был культурным центром казахов, подобно благодатным землям Сырдарьи и Жетысу. Прекрасные пастбища, где располагались зимовки кочевников, близость караванных путей - все это объясняет значительное скопление памятников в данном регионе. Эта гипотеза была подтверждена результатами работ ЦКАЭ, которые внесли поправки в существующую концепцию, согласно которой Центральный Казахстан был транзитной территорией, а оседлая земледельческая культура распространена лишь в южных регионах.

Результаты систематических, более чем 20-летних поисков и исследований на территории Сарыарки, были обобщены в монографии «Древняя культура Центрального Казахстана». Разделы «Добыча руды, обработка металла, камня и кости» первой части и «Бронзолитейное искусство и техника обработки различных материалов» третьей части монографии [Маргулан и др., 1966, с. 266268, 417-418] во многом основаны на данных, собранных и доказанных 
К.И. Сатпаевым. Огромный фактический материал и исследовательский опыт геолога-профессионала позволили представить содержательные выводы, включающие детальную реконструкцию процессов добычи, первичного обогащения и выплавки цветных металлов в эпоху бронзы. Математические подсчеты дали основание предположить количество добытой в древности медной руды, составляющей не менее 1000000 тонн. В статье «Доисторические памятники в Джезказганском районе» К.И. Сатпаев приводит данные о проценте меди в измельченной руде, глубине древних выработок: «Отдельные выработки (разносы) в Джезказгане достигают 750 м в длину, 50 м в ширину и 6-8 м в глубину» [Сатпаев, 2007, с. 69]. Эти и другие выкладки учёного, использованы в указанной монографии. Супруга К.И. Сатпаева Таисия Алексеевна участвовала в химическом анализе бронзовых вещей, который производился в лаборатории Института геологических наук АН КазССР. Кроме этого она подготовила для этого издания приложение «Результаты исследований образцов шлака с Атасуского поселения» [Маргулан и др., 1966, с. 298-300].

Каныш Имантаевич сыграл огромную роль в развитии казахстанской археологии не только как исследователь, но и как талантливый пропагандист и популяризатор научных знаний. Так, в своей статье «Древний Джезказган», опубликованной в газете «Казахстанская правда» в 1936 г., представляя интересные данные об археологических и архитектурных памятниках древнейшей культуры Сарыарки, он подчеркивал важность их сохранения для потомков [Сатпаев, 1936]. Позднее академик писал, что его статьи о многочисленных доисторических памятниках Улытау составлены, главным образом, для того, чтобы показать археологам и краеведам какой разнообразный материал ожидает исследователей в этом районе.

Благодаря энтузиазму и подвижничеству К.И. Сатпаева, был создан первый музей в Жезказганском регионе - геолого-минералогический кабинет, расположенный в пос. Карсакпай, в коллекции которого были представлены и археологические артефакты. С 1947 г. эти фонды вошли в экспозицию Жезказганского геологоархеологического музея, организованного по инициативе Н.В. Валукинского. Как писал в своей статье «Моя полевая работа по археологии» сам Н.В. Валукинский, знакомство с печатными работами К.И. Сатпаева об историческом прошлом Жезказгана, а в 1946 г. и личная встреча с ним «<..> воодушевили меня на поиск и исследование памятников, <..> мест добычи руды и переработки ее» [цит. по: Артюхова, 2017, с. 86]. По предложению академика К.И. Сатпаева в 1950 г. после смерти Николая Васильевича музею было присвоено его имя, что свидетельствовало о высокой оценке вклада исследователя в изучение древней истории региона.

Непосредственная деятельность и организаторский талант первого президента Академии наук КазССР способствовали открытию сектора археологии в Институте истории, археологии и этнографии АН КазССР, созданию ЦентральноКазахстанской археологической экспедиции, формированию национальной школы археологии и профессиональному становлению целой плеяды известных археологов. Он был ответственным редактором периодического издания «Вестник 
$\mathrm{AH}$ КазССР», в котором печатались статьи об археологических исследованиях в Казахстане. К.И. Сатпаев выступал в качестве главного «идеолога» при определении направлений фундаментальных исследований сектора археологии и был «вдохновителем» полевых экспедиций. Можно сказать, что именно он «настраивал компас» археологов, определял вектор движения и помогал привести в систему саму науку. Как нельзя более красноречиво об этом свидетельствует следующий факт из биографии А.Х. Маргулана: именно по совету К.И. Сатпаева он занялся археологическими исследованиями в Центральном Казахстане.

В период «застоя» в социальных науках атмосфера стала очень напряженной, резко усилилась идеологизация и партийное давление. Поэтому Каныш Имантаевич посоветовал А.Х. Маргулану, который в 1946 г. защитил докторскую диссертацию на тему «Эпические сказания казахского народа» и стал заведующим отделом Института истории, археологии и этнографии АН КазССР, организовать крупную экспедицию по исследованию исторических памятников региона. К тому времени многолетние экспедиции по изучению древних памятников на территории Казахстана возглавляли ученые из научных центров Москвы и Ленинграда (А.Н. Бернштам, М.П. Грязнов, С.В. Киселев, О.А. КривцоваГракова, С.С. Черников и др.). Накопление археологического материала позволило приступить к его систематизации и на этом фундаменте провести крупномасштабные по охвату времени и территории исторические исследования.

Когда в 1951 г. А.Х. Маргулан подвергся репрессиям и на время был отстранен от руководства экспедицией и работы заведующего сектором археологии в ИИАЭ АН КазССР, К.И. Сатпаев не мог оставить свое «детище» без руководства и пригласил Л.Р. Кызласова - молодого и подающего большие надежды исследователя - переехать в 1952 г. вместе с семьей в Алма-Ату, чтобы возглавить сектор археологии [Кызласов, 2017, c. 109]. Однако активность А.В. Арциховского* [*д.и.н., зав. кафедрой археологии МГУ - прим. авт.], который всеми силами стремился оставить многообещающего специалиста в Москве, помешала осуществиться этому плану. С 1955 г. должность заведующего сектором археологии ИИАЭ АН КазССР занимал К.А. Акишев, который в юности жил в семье К.И. Сатпаева, будучи его племянником. Интерес Каныша Имантаевича к истории передался его воспитаннику, всю жизнь отдавшему изучению археологии Казахстана.

В апреле 1952 г. К.И. Сатпаева необоснованно обвинили и освободили от руководства Академией наук, предложив «кабинетную» работу в одном из отделов московского Института геологии. Но он не изменил своей гражданской позиции и только после смены власти в 1954 г. ученого признали невиновным [15 интересных...]. В 1955 г. К.И. Сатпаев вновь стал президентом Академии наук Казахской ССР. Интересен факт, что хоздоговорные работы в системе Академии наук Казахстана - именно такое финансирование используется в ходе проведения археологических экспедиций и в настоящее время - были апробированы и внедрены именно К.И. Сатпаевым. Подобная модель рыночных отношений не соответствовала устоям социалистического производства и, как вспоминал 
академик Г.Б. Жилинский* [*соратник К.И. Сатпаева - прим. авт.], сразу после его смерти (январь 1964 г.) был подписан приказ о закрытии всех хоздоговорных работ в системе Академии наук [15 интересных...]. И это в очередной раз доказывает, что масштабность мышления К.И. Сатпаева намного опережала свое время.

С благодарностью вспоминает «путевку в жизнь», выданную К.И. Сатпаевым, ученый-антрополог О. Исмагулов* [*доктор исторических наук, профессор, академик НАН РК, член-корреспондент Болонской академии наук, лауреат премии им. Ч. Валиханова, заслуженный деятель науки и техники РК - прим. авт.]. В 1958 г., когда он работал в музее антропологии при биологическом факультете МГУ и поступил в аспирантуру Института этнологии и антропологии АН СССР, сомневаясь в выборе темы исследования для своей диссертации, молодой исследователь попросил совета у К.И. Сатпаева. Академик лично принял его в Москве, внимательно выслушал и не только помог в конкретизации темы, но очертил глобальную перспективу - исследовать антропологию населения Казахстана, тем самым инициировав разработку комплексной проблемы антропологического состава древнего населения в связи с этноге- незом и этнической историей казахского народа* [*устное выступление академика О. Исмагулова на пленарном заседании Международной археологической научно-практической конференции «Маргулановские чтения - 2019»- прим. авт.].

«Именно с подачи К.И. Сатпаева был задан импульс развитию отечественной археологии» [Бейсенов и др., 2017, с. 24], заложены ее структурные основы. Действительно, на долю этого необыкновенно одаренного и широко образованного человека выпала особая миссия - он принял непосредственное и самое деятельное участие в формировании казахстанской археологии с новой методологией исследований - комплексным культурно-историческим подходом, привлечением широкого круга источников, восхождением от анализа к синтезу. Эту задачу К.И. Сатпаеву удалось выполнить самым блестящим образом благодаря своим неординарным личностным качествам, прекрасной научной подготовке, целеустремленности. Его открытия в области древней и средневековой истории Казахстана стимулируют новые современные исследования и плодотворные дискуссии во имя достижения научной истины.

\section{ЛИТЕРАТУРА}

1. 15 интересных фактов о Каныше Сатпаеве. URL: https://e-history.kz/ru/ publications/view/2771 Дата обращения: 14.05.2019 г.

2. Артюхова O.A. Валукинский Николай Васильевич // Археологическое наследие Центрального Казахстана: изучение и сохранение: сб. научн. ст., посвящ. 70-летию ЦКАЭ АН Казахстана. Отв. ред. А.З. Бейсенов, В.Г. Ломан. Алматы: НИЦИА «Бегазы-Тасмола», 2017. Т. 1. С. 80-87.

3. АКК - Археологическая карта Казахстана. Алма-Ата: Изд-во АН КазССР, 1960. $450 \mathrm{c}$. 
Бедельбаева М.В. Вклад К.И. Сатпаева в становление археологической науки Казахстана

4. Батырбеков Г.О. Академик Сатпаев и его современники. Алматы: «Рауан», 1999. $176 \mathrm{c}$.

5. Бейсенов А.З., Джумабекова Г.С., Базарбаева Г.А. Путь к изучению древностей центра страны: история создания первой археологической экспедиции Казахской академии наук // Археологическое наследие Центрального Казахстана: изучение и сохранение: сб. научн. ст., посвящ. 70-летию ЦКАЭ АН Казахстана. Отв. ред. А.З. Бейсенов, В.Г. Ломан. Алматы: НИЦИА «Бегазы-Тасмола», 2017. Т. 1. C. $11-64$.

6. Григорьев А.П., Телищин Н.Н., Фролова О.Б. Надпись Тимура 1391 г. // Историография и источниковедение истории стран Азии и Африки. 2004. Вып. 21. C. 3-24.

7. Крамаровский М.Г. «Камень Тимура» как феномен чингисидской истории и культуры // Золотая Орда. История и культура. СПб.: «Славия», 2005. С. 167-170.

8. Кызласов И.Л. Археолог Леонид Романович Кызласов. Биографический очерк // Археологическое наследие Центрального Казахстана: изучение и сохранение: сб. научн. ст., посвящ. 70-летию ЦКАЭ АН Казахстана. Отв. ред. А.З. Бейсенов, В.Г. Ломан. Алматы: НИЦИА «Бегазы-Тасмола», 2017. Т. 1. С. 108-118.

9. Лозовский И.Т., Сипайлов Г.А. Студенческие годы Каныша Сатпаева в Томске. Томск: изд-во ТПУ, 1999. 135 с.

10. Маргулан А.Х. К изучению памятников района р. Сары-Су и Улутау // Вестник АН КазССР. 1948. № 2 (35). С. 53-60.

11. Маргулан А.Х., Акишев К.А., Кадырбаев М.К., Оразбаев А.М. Древняя культура Центрального Казахстана. Алма-Ата: «Наука», 1966. 435 с.

12. Могильницкий В.Б. На земле Сатпаева. Караганда: Полиграфия, 1992. 157 с.

13. Потанин Г.Н. Отрывки из киргизского сказания о Идыге (из записей Ч. Валиханова) // Валиханов Ч.Ч. Полн. собр. соч. в 5-ти т. Алма-Ата: Главная редакция Казахской советской энциклопедии, 1985. Т. 5. С. 296-299.

14. Рогожинский A.E. Знаки и надписи «камня Тамгалытас» на окраине Бетпакдалы // Археологическое наследие Центрального Казахстана: изучение и сохранение: сб. научн. ст., посвящ. 70-летию ЦКАЭ АН Казахстана. Отв. ред. А.3. Бейсенов, В.Г. Ломан. Алматы: НИЦИА «Бегазы-Тасмола», 2017. Т. 2. С. 297-307.

15. Боранбаев С. Великое наследие // Индустриальная Караганда. 06.04.1999.

16. Сарсеке М. Феномен. Астана: «Фолиант», 2018. 960 с.

17. Сатпаев К.И. Древний Джезказган // Казахстанская правда. 1936. № 148.

18. Сатпаев К.И. Казахстанская медь // Избранное. В 5-ти т. Шымкент: «Оңтүстік полиграфия», 2007. Т. 3. С. 155-162.

19. Сатпаев К.И. О развитии цветной и черной металлургии в районе Карагандинского бассейна // Избранное. В 5-ти т. Шымкент: «Оңтүстік полиграфия», 2007. Т. 3. С. $115-154$.

20. Сатпаев К.И. Историко-археологические данные о Джезказганском регионе // Избранное. В 5-ти т. Шымкент: «Оңтүстік полиграфия», 2007. Т. 5. С. 44-52.

21. Сатпаев К.И. Доисторические памятники в Джезказганском районе // Избранное. В 5-ти т. Шымкент: «Оңтүстік полиграфия», 2007. Т. 5. С. 69-75.

22. Сатпаева Ш.К. Свет очага. Алматы: Издательский дом «Казахстан», 1999. $184 \mathrm{c}$.

23. Усманова Э.Р., Жумашев Р.М., Джумабеков Ж.А., Антонов М.А., Каспаров A.P. Загадка сопки Алтыншокы: об одном эпизоде похода Тимура против Токтамыша в 1391 г. // Вестник истории, литературы, искусства. Отд-ние ист.-филол. наук РАН. 2018. T. 13. C. 7-24. 


\section{Сведения об авторе:}

Бедельбаева Марина Васильевна - кандидат исторических наук, заведующая музеем археологии и этнографии, Сарыаркинский археологический институт, Карагандинский государственный университет им. академика Е.А. Букетова (г. Караганды, Казахстан); bmv_1967@mail.ru

\section{Қ.И. СӘТБАЕВТЫН ҚАЗАҚСТАН АРХЕОЛОГИЯСЫНЫН ҚАЛЫПТАСУЫНА ҚОСҚАН ҮЛЕСІ}

\section{М.В. Беделбаева}

Академик Қ.И. Сәтбаевтың туғанына 120 жыл толуына арналған мақалада ipi ғалым және дарынды ғылым ұйымдастырушысының Қазақстан археологиясына қосқан үлесі қарастырылады. Жас кезінен бастап зерттеуші ежелгі және ортағасырлық тарихқа қызығушылық танытып, Алтын Орданың кезеңін бейнелейтін қазақ фольклорының үлгілерін тиянақты жинап, жазған. Студенттік жылдары Томск технологиялық университетінде оқып жүріп, ол академиялық кітапханалар мен мұрағаттарда Едіге батыр туралы мәліметтерді жинауды жалғастырды. Орталық Қазақстандағы геологиялық зерттеулер барысында (Қарағанды облысының Ұлытау ауданы) Қ.И. Сәтбаев өткен дәуірлердің материалдық куәліктерін - жекелеген артефактілерді, жартас суреттерін, ежелгі кен қазбаларын, қорғандарды, балбалдарды, кесенелерді, олардың орналасуын бекітумен ғана шектелмей, тарихи контексті кезеңдеу мен қайта жаңғырту әрекеттерін жүзеге асыра отырып, қызығушылықпен сипаттады. Геолог-кәсіпқойдың мазмұнды тұжырымдары түсті металдарды өндіру, бастапқы байыту және балқыту үдерістерін егжей-тегжейлі қайта жаңғыртуды, ал көпжылдық далалық тәжірибеге негізделген математикалық есептеулер ежелгі мыс кенінің кем дегенде бір миллион тоннаны құрайтын санын болжауға мүмкіндік берді. Тарихи көзқарастардың кеңдігі мен далалық зерттеушінің талантына Қ.И. Сәтбаевтың ғылымда Қарсақпай ретінде белгілі Алтыншоқы шоқысында Тамерлан жазуы бар плитаны тауып қана қоймай, сонымен қатар оны зерттеушілерді қазіргі уақытқа дейін жаңа аспектілермен тартатын әлемдік ғылымның игілігі ретінде оқуға мүмкіндік берді. Қ.И. Сәтбаев археологиялық қазбаларға ешқашан қатыспаған болса да, Қазақ КСР Ғылым Академиясының тұңғыш Президентінің тікелей қызметі мен ұйымдастырушылық қабілетінің арқасында Тарих, археология және этнография институтында археология секторының ашылуына, Орталық Қазақстан археологиялық экспедициясының құрылуына, ұлттық археология мектебінің қалыптасуына және белгілі археологтардың тұтас бір тайпаларының кәсіби қалыптасуына ықпал етті.

Түйін сөздер: археология, Қ.И. Сәтбаев, Орталық Қазақстан, ежелгі ескерткіштер, мұражайлар, кеніштер, экспедиция

\section{K.I. SATPAYEV'S CONTRIBUTION IN FORMATION OF ARCHAEOLOGICAL SCIENCE OF KAZAKHSTAN}

\section{M.V. Bedelbayeva}

The article is devoted to the $120^{\text {th }}$ anniversary of Academician K.I. Satpayev, it also considers contribution of the great scientist and talented organizer of science to the archaeology of Kazakhstan. The researcher from his youth was actively interested in ancient and medieval history, enthusiastically collected and recorded samples of oral folk art of Kazakhs, reflecting the Golden Horde period. In his student years, studying at Tomsk Technological University, he continued to collect materials about Yedige-batyr in academic libraries and archives. In the course of geological surveys in Central Kazakhstan (Ulytau district of Karaganda region) K.I. Satpayev described with interest the material evidence 
of bygone eras - individual artifacts, rock paintings, ancient ore mining, mounds, menhirs, balbals, mausoleums, not limited to fixing their location, and making attempts to periodize and reproduce the historical context. The geologist-professional's substantial conclusions included a detailed reconstruction of the processes of extraction, primary enrichment and smelting of non-ferrous metals, and mathematical calculations based on years of field experience, allowed to assume the amount of copper ore mined in ancient times, amounting to at least one million tons. A width of historical views and talent of the field researcher has allowed K.I. Satpayev not only found a plate with the inscription of Tamerlan on the hill Altynshoky known in science as "Karsakpay", but also to make its reading the property of the world science, attracting researchers with new aspects up to the present time. And although K.I. Satpayev himself never participated in archaeological excavations, the direct activity and organizational talent of the first President of the Academy of Sciences of the Kazakh SSR contributed to the opening of the sector of archaeology at the Institute of history, archeology and ethnography, the creation of the Central Kazakhstan archaeological expedition, the formation of the national school of archaeology and professional formation of a whole galaxy of famous archaeologists.

Keywords: archaeology, K.I. Satpayev, Central Kazakhstan, ancient monuments, museums, mines, expedition

\section{REFERENCES}

1. 15 interesnyh faktov o Kanyshe Satpaeve (15 interesting facts about Kanysh Satpayev). URL: https://e-history.kz/ru/publications/view/2771 (in Russian).

2. Artyukhova, O. A. 2017. In Beisenov, A. Z. (eds.) Arkheologicheskoye naslediye Tsentralnogo Kazakhstana (Archaeological heritage of Central Kazakhstan), 1. Almaty: «Begazy-Tasmola» Publ., 80-87 (in Russian).

3. Arkheologicheskaya karta Kazakhstana (Archaeological Map of Kazakhstan). 1960. Alma-Ata: AN KazSSR (in Russian).

4. Batyrbekov, G. O. 1999. Akademik Satpayev i ego sovremenniki (Academician Satpayev and his contemporaries). Almaty: «Rauan» (in Russian).

5. Beisenov, A. Z., Jumabekova, G. S., Bazarbayeva, G. A. 2017. In Beisenov, A. Z., Loman, V. G. (eds.) Arkheologicheskoyenaslediye Tsentralnogo Kazakhstana (Archaeological heritage of Central Kazakhstan), 1. Almaty: «Begazy-Tasmola» Publ., 11-64 (in Russian).

6. Grigoryev, A. P., Telitsina, N. N., Frolova, O. B. 2004. In Istoriografiya $i$ istochnikovedeniye istorii stran Azii i Afriki (Historiography and source study of the history of Asian and African countries), 21, 3-24 (in Russian).

7. Kramarovskiy, M. G. 2005. In Zolotaya Orda. Istoriya i kultura (Golden Horde. History and culture). Saint Petersburg: «Slaviya» Publ., 167-170 (in Russian).

8. Kyzlasov, I. L. 2017. In Beisenov, A. Z., Loman, V. G. (eds.) Arkheologicheskoye naslediye Tsentralnogo Kazakhstana (Archaeological heritage of Central Kazakhstan), 1. Almaty: «Begazy-Tasmola» Publ., 108-118 (in Russian).

9. Lozovskii, I. T.. Sipailov, G. A. 1999. Studencheskiye gody Kanysha Satpayeva v Tomske (Student years Kanysh Satpayev in Tomsk). Tomsk: Tomsk Pedagogical University Publ. (in Russian).

10. Margulan, A. Kh. 1948. In Vestnik AN KazSSR (Bulletin of the Academy of Sciences of the Kazakh SSR), 2 (35), 53-60 (in Russian).

11. Margulan, A. Kh., Akishev, K. A., Kadyrbayev, M. K., Orazbayev, A. M. 1966. Drevnyaya kultura Tsentralnogo Kazakhstana (Ancient culture of Central Kazakhstan). Alma-Ata: «Nauka» Publ. (in Russian).

12. Mogilnitskii, V. B. 1992. Na zemle Satpaeva (On the ground Satpayev). Karaganda: «Poligrafiya» (in Russian). 
13. Potanin, G. N. 1985. In Margulan, A. Kh. (ed.). Valihanov, Ch. Ch. Polnoe sobranie sochineniy v 5-ti tomah (Valikhanov Ch.Ch. Full collected works in 5 toms), 5. Alma-Ata: Glavnaya redaktsiya Kazahskoy sovetskoy entsiklopedii, 296-299 (in Russian).

14. Rogozhinskiy, A. E. 2017. In Beisenov, A. Z., Loman, V. G. (eds.) Arkheologicheskoye naslediye Tsentralnogo Kazakhstana (Archaeological heritage of Central Kazakhstan), 2. Almaty: «Begazy-Tasmola» Publ., 297-307 (in Russian).

15. Boranbayev, S. 1999. In Industrialnaya Karaganda (Industrial Karaganda), 06.04, 7 (in Russian).

16. Sarseke, M. 2018. Fenomen. Astana: «Foliant» (in Russian).

17. Satpayev, K. I. 1936. In Kazahstanskaya Pravda, 148 (in Russian).

18. Satpayev, K. I. 2007. In Izbrannoe. V 5-ti t. (Favorites. In 5 vol.), 3. Shymkent: «Ontustik poligrafiya» Publ., 155-162 (in Russian).

19. Satpayev, K. I. 2007. In Izbrannoe. V 5-ti t. (Favorites. In 5vol.), 3. Shymkent: «Ontustik poligrafiya» Publ., 115-154 (in Russian).

20. Satpayev, K. I. 2007. In Izbrannoe. V 5-ti t. (Favorites. In 5 vol.), 5. Shymkent: «Ontustik poligrafiya», 44-52 (in Russian).

21. Satpayev, K. I. 2007. In Izbrannoe. V 5-ti t. (Favorites. In 5 vol.), 5. Shymkent: «Ontustik poligrafiya», 69-75 (in Russian).

22. Satpayeva, Sh. K. 1999. Svet ochaga (Light of the hearth). Almaty: Izdatelskiy dom «Kazahstan» (in Russian).

23. Usmanova, E. R., Zhumashev, R. M., Jumabekov, Zh. A., Antonov, M. A., Kasparov, A. R. 2018. In Vestnik istorii, literatury, iskusstva (Bulletin of history, literature, art), 13, 7-24 (in Russian).

\section{About the Author:}

Bedelbayeva Marina V. Candidate of historical sciences, director archaeology and ethnography museum, Saryarka archaeological Institute, academician E.A. Buketov Karagandy State University, Karagandy, Kazakhstan; bmv_1967@mail.ru

\footnotetext{
Мүдделер қақтығысы туралы ақпаратты ашу. Автор мүдделер қақтығысының жоқтығын мәлімдейді.

/ Раскрытие информации о конфликте интересов. Автор заявляет об отсутствии конфликта интересов

/ Disclosure of conflict of interest information. The author claim no conflict of interest.

Мақала туралы ақпарат / Информация о статье / Information about the article.

Редакцияға түсті / Поступила в редакцию / Entered the editorial office: 14.05.2019.

Рецензенттер мақұлдаған / Одобрено рецензентами / Approved by reviewers: 21.05.2019.

Жариялауға қабылданды / Принята к публикации / Accepted for publication: 28.05.2019.
} 